Studia Judaica 22 (2019), nr 2 (44), s. 285-304

doi:10.4467/24500100STJ.19.013.12396

Przemysław Tacik iD https://orcid.org/0000-0001-7174-1752

\title{
Przyczynek do pozagładowego lurianizmu. Droga żelazna Aharona Appelfelda
}

\author{
A CONTRIBUTION TO THE POST-SHOAH LURIANISM: \\ THE IRON TRACKS BY AHARON APPELFELD
}

\begin{abstract}
The article reinterprets The Iron Tracks by Aharon Appelfeld as a work of Lurianic Kabbalah adapted to the world after the Shoah. It is a reality of collapsed transcendence in which no divinity or ethics hold universal validity. As in Lurianism, this world contains entrapped sparks of former transcendence: dispersed Jewish survivors, artefacts of Jewish life and a Jewish Communist organization. Appelfeld portrays a post-survival world based on permanent repetition and unrepented guilt. The gist of his novel, however, lies in the slim possibility of redemption which the main protagonist, Erwin Siegelbaum, opens up with an act of vengeance on a war criminal.
\end{abstract}

Keywords: Aharon Appelfeld, The Iron Tracks, Shoah, Kabbalah, Lurianism.

Słowa kluczowe: Aharon Appelfeld, Droga żelazna, Zagłada, kabała, lurianizm.

\section{Wprowadzenie}

Wśród pisarzy zmagających się z opowiadaniem o Szoah niedawno zmarły Aharon Appelfeld (1932-2018) zajmuje miejsce specyficzne: jego proza jest nie tyle o Zagładzie, ile raczej po niej. W miejscu, gdzie można by się spodziewać świadectwa czy bezpośredniego odniesienia, zieje pustka zdarzenia, które poznajemy albo przez jego zapowiedź, albo za pośrednictwem skutków, jakie pociągnęło. Literatura Appelfelda sytuuje bohaterów tuż przed progiem katastrofy wiszącej nad przedstawianym światem jak niemożliwe do odsunięcia przeznaczenie - niczym burza, która zatrzymuje 
się na moment przed właściwym uderzeniem; niekiedy zaś, przeciwnie, proza ta umieszcza ich w pustym, postapokaliptycznym świecie, który Zagłada nieodwracalnie wypaczyła. W obu przypadkach Zagłada pozostaje ciemnym jądrem historii, das Ereignis Auschwitz - by zacytować Milchmana i Rosenberga ${ }^{1}$. Jej bezpośrednie przedstawianie nie tyle nie jest niemożliwe, co zostaje przesłonięte przez tektoniczne przekształcenie ontologii całej rzeczywistości.

Kontrast obu strategii - przedstawiania świata tuż przed Zagładą oraz relacjonowania jego pustki po Szoah - jest wyraźnie dostrzegalny w opozycji dwóch powieści Appelfelda: Badenheim 1939 (Badenheim ir nofesz, 1978)² oraz Drogi żelaznej (Mesilat barzel, 1991) ${ }^{3}$. Obie opisują krainę przypominającą - językiem, nastrojem, zwyczajami i nazwami miejscowości - peryferia Austro-Węgier. O ile jednak pierwsza z powieści przedstawia austriacki kurort, który z dnia na dzień, wraz z rozwojem wypadków po anszlusie, staje się więzieniem dla żydowskich letników, ostatecznie ładowanych do wagonów i oczekujących na wywózkę - o tyle Droga żelazna to głos z tej samej krainy dotkniętej już katastrofą Zagłady. To właśnie ta powieść jest pierwszą, w której Appelfeld podejmuje na wpół autobiograficzny rozrachunek z Szoah - usiłując zakreślić, niczym wcześniej Paul Celan5, kontury i reguły funkcjonowania nowej, pozagładowej rzeczywistości.

Droga żelazna to powieść niezwykle przenikliwa, wielopłaszczyznowa, językowo oszczędna, a w tej oszczędności wręcz boleśnie precyzyjna. Jak spróbuję pokazać w niniejszym artykule, można ją czytać jak szeroko zakrojony traktat filozoficzny o świecie, który na trwałe uległ rozpadowi i całkowitemu przewartościowaniu. W takiej lekturze stanowi ona zarazem quasi-kabalistyczny traktat o zbawieniu, zaszyfrowany w niemal zupełnie zeświecczonym języku. Zbawienie, o którym w nim mowa, można widzieć jak pozagładową reinterpretację luriańskiej kabały. Ta „głęboko pesymistyczna, wręcz rozpaczliwa, najciemniejsza z książek Appelfelda" ${ }^{\circ}$, jak

${ }^{1}$ Zob. Alan Milchman, Alan Rosenberg, Eksperymenty w myśleniu o Holocauście. Auschwitz, nowoczesnośćifilozofia, tłum.Leszek Krowicki,Jakub Szacki, Warszawa2003,s.11-16.

${ }^{2}$ Zob. Aharon Appelfeld, Badenheim 1939, thum. Henryk Szafir, Warszawa 2004.

${ }^{3}$ Zob. Aharon Appelfeld, Droga żelazna, tłum. Hanna Volovici, Warszawa 2006.

${ }^{4} \mathrm{Na}$ temat tej powieści i jej kontekstu historycznego zob. Michael André Bernstein, Foregone Conclusions: Against Apocalyptic History, Berkeley 1994, s. 59-71.

${ }_{5}$ Zob. Paul Celan, Przemówienie z okazji przyjmowania Nagrody Literackiej Wolnego Hanzeatyckiego Miasta Bremy, tłum. Feliks Przybylak, [w:] tenże, Utwory wybrane, red. Ryszard Krynicki, Kraków 1998, s. 317.

${ }^{6}$ Zob. John Maxwell Coetzee, Whither Dost Thou Hasten?, „The New York Review of Books" (March 5, 1998), s. 19. 
napisał o niej John Maxwell Coetzee, byłaby w tej perspektywie tekstem o stworzeniu nowego świata, które równoznaczne jest z katastrofą.

Podkreślenia wymaga, że niniejszy artykuł nie stanowi ani wyczerpującej egzegezy prozy Appelfelda, ani też studium recepcji lurianizmu. Nie opiera się również na szczegółowym badaniu wpływu kabały luriańskiej na twórczość autora Drogi żelaznej. Przedstawia raczej interpretacyjną propozycję traktującą lurianizm, podobnie jak czynił to Harold Bloom? jako par excellence nowoczesny mit, powracający w niezliczonych przekształceniach i pozwalajacy rzucić światło na funkcjonowanie modernitas ${ }^{8}$. Samo porównanie twórczości Appelfelda z kabałą luriańską (szczególnie we wpływowej w dwudziestym wieku reinterpretacji Scholema skoncentrowanej na samowycofaniu Boga ${ }^{9}$ ) nie jest ani nowe ${ }^{10}$, ani zaskakujacce, jednak ponad oczywistą siecią skojarzeń albo ewentualnych wpływów rozciąga się możliwość konsekwentnej lektury Drogi żelaznej jako zupełnie swoistej pozagładowej wersji lurianizmu.

\section{Epistemologia wypartej pamięci}

Droga żelazna, jak wiele innych książek Appelfelda, przetwarza motywy autobiograficzne, jest jednak pierwszą powieścią, która sięga do wcześniej zamkniętego obszaru pamięci Zagłady. W tym miejscu świat, którego właściwości ów tekst stara się nakreślić, staje się równie niedostępny jak sama pamięć. We wstępie do wydanej w 1999 r. autobiograficznej powieści Sipur chajim Appelfeld tak opisuje jej rolę i jednoczesną niemożliwość:

Od dzieciństwa czułem, że pamięć jest żywym i kipiącym zbiornikiem, który tchnie życie w moje istnienie. [...] Jest zdumiewające, jak wyraziste mogą być nawet

7 Zob. Harold Bloom, Lęk przed wptywem. Teoria poezji, thum. Agata Bielik-Robson, Marcin Szuster, Kraków 2002; tenże, A Map of Misreading, Oxford 1975; tenże, Kabbalah and Criticism, New York 1975.

${ }^{8}$ Zob. również w tym paradygmacie: Agata Bielik-Robson, Jewish Cryptotheologies of Late Modernity: Philosophical Marranos, London-New York 2015.

${ }^{9}$ Scholem zwykle podawał swoją interpretację lurianizmu pod maską obiektywnej historycznej narracji. Swoim poglądom dał jednak wyraz w kilku tekstach - zob. np. Gershom Scholem, Zehn unhistorische Sätze über Kabbala, [w:] tenże, Judaica 2, Frankfurt am Main 1970, s. 266; tenże, Reflections on the Possibility of Jewish Mysticism in Our Time, [w:] tenże, On the Possibility of Jewish Mysticism in Our Time and Other Essays, red. Avraham Shapira, thum. Jonathan Chipman, Philadelphia-Jerusalem 1997, s. 6-18. Na temat Scholema jako gnostyckiego reinterpretatora kabały zob. Moshe Idel, Absorbing Perfections: Kabbalah and Interpretation, New Haven-London 2002, s. xi.

${ }_{10}$ Zob. Emily Miller Budick, Aharon Appelfeld's Fiction: Acknowledging the Holocaust, Bloomington-Indianapolis 2005, s. 60-77. 
najodleglejsze i najbardziej ukryte moje wspomnienia z dzieciństwa, szczególnie te związane z Karpatami i szerokimi równinami, które rozpościerają się u ich podnóży. Podczas ostatnich wakacji przed wojną nasze oczy napawały się widokiem gór i równin z trwożną tęsknotą, jak gdyby moi rodzice wiedzieli, że będą to ostatnie wakacje, a od tego momentu życie stanie się piekłem.

Gdy wybuchła druga wojna światowa, miałem siedem lat. Sekwencja czasu została zakłócona - koniec z latem i zimą, koniec z długimi wizytami u dziadków na wsi. Nasze życie zostało wtłoczone w ciasny pokój. Przez jakiś czas byliśmy w getcie, a pod koniec jesieni zostaliśmy z niego wyrzuceni. Przez tygodnie byliśmy w drodze, a potem wreszcie w obozie, z którego udało mi się uciec.

[...] Z wojennych lat pamiętam tak niewiele, jak gdyby nie były sześcioma następującymi po sobie latami. To prawda, że czasem obrazy podnoszą się z gęstej mgły: ciemna postać, nadpalona ręka, but, z którego nie zostało nic prócz strzępów. Te obrazy, czasem dzikie jak płomień pieca, blakną szybko, jakby nie dając się odkryć, i znów wraca ten sam czarny tunel, który nazywamy wojną. To jest granica świadomej pamięci. Lecz dłonie, podeszwy stóp, plecy i kolana pamiętają więcej niż pamięć. Gdybym wiedział, jak z nich czerpać, zostałbym przytłoczony przez to, co widziałem. Niekiedy bywałem zdolny wsłuchać się w swoje ciało i napisać parę rozdziałów, ale nawet one są ledwie fragmentami pulsującej ciemności, na zawsze zatrzaśniętymi wewnątrz mnie ${ }^{11}$.

Pamięć, równoznaczna z samym warunkiem przywoływania i opowiadania, zostaje przez katastrofę Zagłady odcięta od świadomości i zamknięta w ciele. Pisarza takiego jak Appelfeld, który wielokrotnie dawał wyraz przekonaniu, że każde pisarstwo jest dziełem przetworzenia pamięci, stawia to przed wyzwaniem przebicia się przez spowijającą świadomość zasłonę wyparcia. Jej nie mniej istotną częścią był powojenny klimat duchowy Izraela, skupiony na budowie nowego państwa i nowego człowieka, odcinający się od cierpień Żydów z diaspory ${ }^{12}$. W tej sytuacji jedną z możliwości odnalezienia pamięci jest zbieranie ułomków - kolekcjonowanie obrazów, które w swojej oderwanej jednostkowości zdolne są przekroczyć zaporę świadomego (nie)pamiętania. Inną opcją jest zaangażowanie ciała do procesu przywracania wspomnień. We wszystkich tych przypadkach pamięć nie odtwarza spójnej historii, ponieważ spójną historią jest właśnie zasłona skrywająca utrwalone zdarzenia, ów „czarny tunel”. To, co zostaje odpomniane, przybiera zatem postać fragmentów wdrukowanych w ciało lub nawiedzających spójność czarnej historii skrywającej wojenne wspomnienia.

${ }^{11}$ Zob. Aharon Appelfeld, The Story of a Life, thum. Aloma Halter, New York 2004, s. vii. Wszystkie przekłady cytatów, jeśli nie są oznaczone inaczej, zostały dokonane przez autora artykułu.

12 Tamże, s. viii-ix. 
Droga żelazna nie jest więc w żadnej mierze powieścią autobiograficzną, choć ze specyficznych powodów. Jakkolwiek zawiera elementy zaczerpnięte z życia autora, nie tylko nie stara się bezpośrednio odnosić do wydarzeń i doświadczeń Zagłady (skupia się bowiem na opisie rzeczywistości już po Szoah), ale przedstawia świat równie sfragmentaryzowany i rozproszony jak pozagładowa pamięć. Spróbujmy więc prześledzić te pojedyncze „obrazy-błyski”, by użyć wyrażenia Waltera Benjamina ${ }^{13}$, które jak cienkie nici łączą rzeczywistość Drogi żelaznej z kontekstem życia Appelfelda.

Pierwszym elementem, który w tym kontekście rzuca się w oczy, jest sama geograficzno-kulturowa rama powieści nawiązująca do miejsc dzieciństwa jej autora. Pisarza uznać można za pogrobowca Austro-Węgier: Appelfeld, urodzony w Jadowej na Bukowinie w 1932 r., aż do początku wojny żył w tym zakątku dawnego habsburskiego imperium. Jego rodzina mieszkała w Czerniowcach; obaj dziadkowie byli chasydami, w tym jeden - sadagórskim ${ }^{14}$. Sadagóra - ów „bukowiński Safed”, ważne centrum żydowskiego mistycyzmu położone po przeciwnej stronie Prutu niż Czerniowce - miała też istotne znaczenie dla Celana, którego matka wywodziła się z kręgu tamtejszych chasydów ${ }^{15}$. Podobnie jak w przypadku czerniowieckiego poety ojczystym językiem Appelfelda był niemiecki - kultywowany przez zasymilowanych Żydów Bukowiny z przysłowiową gorliwością, również wtedy, gdy po upadku Austro-Węgier wiedeński styl życia stracił powab uniwersalności i zaczął być wypierany przez kulturę narodową Wielkiej Rumunii, w skład której weszła Bukowina. Żydowska społeczność, żywiołowo rozwijająca się w imperium, straciła wówczas oparcie, którym ideologia państwa Habsburgów osłaniała wielokulturowość i multietniczność. W tym sensie Żydzi bukowińscy - nawet ci, którzy urodzili się już po 1918 r., jak Celan i Appelfeld - stali się sierotami po Austro-Węgrzech. Wielojęzyczność, asymilacja i rozsianie rodzin po dawnych habsburskich ziemiach były typowymi cechami ówczesnych społeczności żydowskich. Samego autora Drogi żelaznej wojna niemiecko-radziecka zastała w Drohobyczu, gdzie wyjechał na lato do swoich dziadków ${ }^{16}$. Ten świat rozległych habsburskich terytoriów - zatrzymany w nostalgicznym

${ }_{13}$ Zob. Walter Benjamin, Park centralny, thum. Hubert Orłowski, [w:] tenże, Anioł historii. Eseje, szkice, fragmenty, Poznań 1996, s. 405.

${ }_{14}$ Zob. Gila Ramras-Rauch, Aharon Appelfeld: The Holocaust and Beyond, Bloomington-Indianapolis 1994, s. 5.

15 Zob. John Felstiner, Paul Celan. Poeta, ocalony, Żyd, thum. Maciej Tomal, Małgorzata Tomal, Kraków-Budapeszt 2010, s. 24-26.

${ }_{16}$ Zob. Ramras-Rauch, Aharon Appelfeld..., s. 5. 
spojrzeniu m.in. przez Josepha Rotha ${ }^{17}$ i Brunona Schulza ${ }^{18}$ - u Appelfelda zostaje odtworzony już po katastrofie jako wszechogarniająca, pozbawiona granic przestrzeń, w której żyją obok siebie sprawcy, ofiary i świadkowie. Multietniczność i wielojęzykowość austro-węgierskiej Bukowiny zostaje tutaj, jak w ponurym śnie, przetworzona w niedookreśloną geograficznie i historycznie krainę, zamieszkałą przez Żydów, Niemców i Rusinów, w której jedynym pewnikiem jest to, że ludobójstwo naznaczyło wszystkich na zawsze. Tym samym pohabsburskie dziedzictwo Appelfelda pozwala mu uchwycić wewnętrzne sprzeczności przekwitającego imperium - z jednej strony rozległego państwa jednoczącego różnorodne terytoria, ludy, języki i religie, z drugiej zaś - miejsca wylęgania się totalnych ideologii, buzującego antysemityzmu i nadciągającej katastrofy.

Jak zauważa Joseph Cohen w odniesieniu do Badenheim 1939, powieści opisującej pohabsburską przestrzeń tuż przed Zagładą:

podstawą tej mocy, wizji i zasięgu jest osobliwe ewokowanie nastroju przez Appelfelda oraz jego wyczucie czasu i miejsca w całościowym odtwarzaniu utraconego świata środkowoeuropejskich Żydów, świata, który istniał tuż przed eksterminacją dokonaną przez szwadrony Hitlera. Inwencja Appelfelda widmowo przywołuje biografie i poglądy tych europejskich Żydów, którzy byli tak głęboko zanurzeni w kulturze niemieckiej, tak dogłębnie zasymilowani i tak materialistyczni, że ani nie mieli zdolności przewidzenia tragedii, która na nich spadła, ani nie posiadali środków, by ją przepracować poprzez jej powiązanie z żydowską historią apokaliptyczną. Możliwość, że następny rozdział tej historii zostałby napisany własną krwią zasymilowanej żydowskiej społeczności, była nie do pomyślenia ${ }^{19}$.

Droga żelazna natomiast przedstawia tę samą krainę - ciemną, opustoszałą, oficjalnie prosperującą, a tak naprawdę zmagającą się z nieprzepracowaną i ledwo skrywaną winą - już po dziejowej katastrofie.

Drugim zasadniczym wątkiem, który na prawach sfragmentaryzowanego obrazu łączy świat przedstawiony Drogi żelaznej z życiem Appelfelda, jest wspomnienie rzeczywistości obozowej. Główny bohater powieści, Erwin Siegelbaum (Erwin to także pierwsze imię samego pisarza), jest ocalałym z Zagłady, który przetrwał niemiecki obóz pracy zarządzany przez okrutnego komendanta, Nachtigala. Appelfeld po likwidacji getta

17 Zob. Joseph Roth, Krypta kapucynów, tłum. Józef Wittlin, Kraków-Budapeszt 2015; tenże, Marsz Radetzky'ego, tłum. Wanda Kragen, Kraków-Budapeszt 2015.

${ }_{18}$ Zob. Bruno Schulz, Wiosna, [w:] tenże, Sklepy cynamonowe. Sanatorium pod Klepsydra, Kraków 1985, s. 142-197.

${ }^{19}$ Zob. Joseph Cohen, Voices of Israel: Essays on and Interviews with Yehuda Amichai, A. B. Yehoshua, T. Carmi, Aharon Appelfeld and Amos Oz, Albany 1990, s. 107. 
czerniowieckiego, gdzie przebywał, został wraz z ojcem zmuszony do marszu do Transnistrii (Naddniestrza) ${ }^{20}$ - terytorium zarządzanego przez sprzymierzoną z III Rzeszą Rumunię, które Raul Hilberg określił mianem „obszaru rozciągniętej w czasie katastrofy"21: obozów pracy i szybkiej śmierci $^{22}$. Z kolei Nachtigal jest ucieleśnieniem fanatycznego wojennego zbrodniarza, który nie tylko unika kary, ale wraca do rodzinnych okolic otoczony szacunkiem splamionej ludobójstwem społeczności:

O ile mi wiadomo, Nachtigal liczy sobie teraz siedemdziesiąt dwa lata. Był żonaty, ale nie ma dzieci. W czasie wojny jego żona trudniła się wysyłaniem ciepłych ubrań na front. Nachtigal przyjeżdżał kilka razy ze Lwowa na urlop do domu. Żony nie zabrał na Wschód. Zaczął karierę na Bukowinie, potem został przeniesiony do Galicji i wreszcie skończył swą służbę w centralnej Polsce. We wszystkich tych miejscach był szefem obozów pracy. Ludzi słabych i mało wydajnych zabijał. Silnych i mających konkretny zawód trzymał przez pewien czas pod nadzorem, bił ich i znęcał się nad nimi tak długo, aż tracili siły i umierali. Na ich miejsce przysyłano nowych. Za dobre wyniki i poświęcenie przy wykonywaniu obowiązków awansował w służbie, otrzymywał także odznaczenia.

Zaraz po wojnie zbiegł do Urugwaju, mieszkał tam wśród innych oficerów uciekinierów, a w 1968 roku wrócił i osiadł w okolicy Zwirenu. Od czasu do czasu przeprowadzał się. Miał do dyspozycji trzy domy: jeden własny i dwa odziedziczone. Na początku ochraniali go jego dawni żołnierze, których najął do tego zajęcia. Po śmierci żony przestał się bać i osiedlił się w Steinbergu. W końcu kupił sobie nowy dom w pięknym Weinbergu, w okolicy, w której spędził dzieciństwo ${ }^{23}$.

Jednym z głównych wątków Drogi żelaznej jest problem wyegzekwowania odpowiedzialności za winę, której uznaniu sprzeciwia się nie tylko sam zbrodniarz, ale i społeczność, do której należy. Główny bohater powieści dąży do samotnej zemsty w imieniu sprawiedliwości oraz ocalałych - tylko po to, by dowiedzieć się, że świat pogrążony jest w apologii zbrodni i zasługuje na zniszczenie.

Ostatnim istotnym obrazem-błyskiem, który regularnie powraca w Drodze żelaznej - łącząc ją z Zagładą - jest kolej żelazna ${ }^{24}$. Ten kluczowy topos Szoah ${ }^{25}$ - ikona zarazem nowoczesności i nowoczesnego ludobójstwa ${ }^{26}$

${ }^{20}$ Zob. Ramras-Rauch, Aharon Appelfeld..., s. 6.

${ }_{21}$ Zob. Raul Hilberg, Zagłada Żydów europejskich, thum. Jerzy Giebułtowski, Warszawa 2014, t. 2, s. 964.

${ }^{22}$ Tamże, s. 967-968.

${ }^{23}$ Zob. Appelfeld, Droga żelazna..., s. 160-161.

${ }^{24}$ Zob. też Miller Budick, Aharon Appelfeld's Fiction ..., s. 52-53.

${ }_{25}$ Zob. Iwona Kurz, Wagon, [w:] Ślady Holokaustu w imaginarium kultury polskiej, red. Justyna Kowalska-Leder i in., Warszawa 2017, s. 413-446.

${ }^{26}$ Zob. Wojciech Tomasik, Szalony bieg. Kolej i ciemna nowoczesność, Warszawa 2015. 
- jest centrum sieci metafor w powieści Appelfelda. Siegelbaum nie ma stałego domu: przemierza pociągami pozagładowo-pohabsburskie terytoria, powtarzając $\mathrm{w}$ corocznym rytmie ${ }^{27}$ żelazny plan odwiedzenia kolejnych, tych samych miejscowości. Tytuł powieści literalnie znaczy tyle co „szyna”: „droga żelazna” jest przekładem umownym, zaznaczającym nie tylko złożenie słów mesila („drogi”, „ścieżki”) i barzel („żelaza”) - z ich odrębnymi konotacjami - ale także przywołującym indoeuropejską etymologię tego wyrażenia (Eisenbahn, chemin de fer, żeleznaja doroga). Mesilat barzel jest zatem złożeniem opisującym ścieżkę - podróży, ale i życia - z ciążącym nad nią widmem konieczności symbolizowanym przez nienegocjowalny kierunek, w którym prowadzą szyny. To wyrażenie, także przez swoje europejskie źródło, nawiązuje wprost do Zagłady. W samej powieści jest łącznikiem pomiędzy koleją jako jednym z podstawowych przemysłowych narzędzi Szoah a - z jednej strony - życiem Siegelbauma, na zawsze wtłoczonym w koleiny bycia ocaleńcem, z drugiej zaś - przymusem powtarzania podróży, który na owym bohaterze ciąży. Kolej żelazna i całe związane z nią imaginarium - pociągi, tory, dworce i stacyjki, nieustanna podróż i kondycja transportowanego pasażera - stanowi więc w istocie sieć obrazów odwzorowujących w powojennym życiu Siegelbauma traumę toru, na którym znalazł się w czasie Zagłady.

Jego coroczna wędrówka zaczyna się w miejscowości Wirblbahn, której nazwa - pobrzmiewająca bawarsko-austriackimi dialektami niemczyzny - również jest znacząca: Wirbel to „wir”, Bahn to „ścieżka”, „droga” i „kolej” zarazem. Oryginalny termin Freuda na „torowanie”, jedną z jego najwcześniejszych fizjologicznych koncepcji oznaczającą proces psychiczny polegający na wytworzeniu przez bodziec ścieżki rozładowania warunkującej następnie funkcjonowanie aparatu psychicznego, to Bahnung ${ }^{28}$. Miejscowość Wirblbahn poznajemy jako punkt początkowy corocznej wędrówki Siegelbauma:

Trasa, którą przejeżdżam w ciągu roku, tworzy zamknięte koło. Właściwie jest to owal. Podróż zaczyna się wiosną, a kończy wraz z odejściem zimy. Jest na tej trasie wiele stacji, ale dla mnie liczą się tylko dwadzieścia dwie. Znam je jak własną kieszeń, trafiłbym tam z zamkniętymi oczami. Gdy kilka lat temu zdarzyło się, że pociąg nie zatrzymał się na jednej z owych małych stacji, moje ciało drgnęło. Więcej mam zaufania do swego ciała niż do rozumu. Ciało natychmiast wykrywa błąd.

27 Zob. Ramras-Rauch, Aharon Appelfeld..., s. 190.

${ }_{28}$ Zob. Jean Laplanche, Jean-Bertrand Pontalis, Vocabulaire de la psychanalyse, Paris 2007, s. 172 (przekład polski: Stownik psychoanalizy, tłum. Ewa Wojciechowska, Ewa Modzelewska, Warszawa 1996). 
Co roku dwudziestego siódmego marca zaczynam swoją podróż. Opuszczam Wirblbahn rannym pociągiem. Wolę pociągi poranne od popołudniowych ekspresów. Pociągi ekspresowe przyprawiają mnie o zawroty głowy. Tak jest do dziś. Całą noc przed wyjazdem nie śpię, stoję koło okna i czekam na werdykt. Jeśli niebo jest jasne, to znak, że moje tegoroczne podróże udadzą się tak, jak je zaplanowałem, a ludzie będą wobec mnie życzliwi. Ale jeśli niebo jest pochmurne i ciemne, z góry wiem, że cały rok będzie nieudany, będą na mnie napadać chuligani, no i niewiele zarobię ${ }^{29}$.

Wirblbahn reprezentuje więc rodzaj przekleństwa nieustającego powrotu, miejscowość będącą początkiem i końcem „torowania”, którego doznał Siegelbaum. Odciska się ono nie tylko w jego aparacie psychicznym - jak Freudowskie Bahnung - ale i w ciele, które lepiej niż świadoma pamięć przechowuje coroczną trasę. Związek między Wirblbahn a doświadczeniem Zagłady poznajemy już po tym, gdy Siegelbaum opuszcza miejscowość:

O siódmej rano stoję z walizką w ręku na stacji kolejowej w Wirblbahnie. Ilekroć stąd wyjeżdżam albo tu wracam, ogarnia mnie lęk. Nogi się pode mną uginają i czuję ucisk w żołądku. Taki atak mogą uśmierzyć tylko dwie tabletki uspokajające. Z powodu tych właśnie lęków, a także z innych jeszcze przyczyn, chciałem zmienić miejsce, z którego wyruszam w moje podróże. Dotąd jednak tego nie zrobiłem i zaraz wyjaśnię dlaczego: to właśnie w tym nizinnym Wirblbahnie, w którym nie ma nic poza ulicą pełną składów towarowych, kilkoma barakami dla strażników i jednym nędznym hotelikiem, w tym właśnie przeklętym miejscu kiedyś umarłem i znowu się narodziłem. Niemcy przywieźli nas do tej zapadłej dziury i zostawili. Trzy dni jechaliśmy w zaryglowanych wagonach; trzeciego dnia pociąg się zatrzymał. Skrzydła śmierci oddaliły się, ale my nie wiedzieliśmy o tym. Pogrążyliśmy się już w rojeniach o niej. Następnego ranka ktoś odsunął rygiel i zalał nas strumień światła. To był nasz powrót do życia. Nadal to czuję całym swoim ciałem. Moje dziwne życie zaczęło się tego właśnie ranka. Czasami wydaje mi się, że w ogóle wszystko zaczęło się tego ranka ${ }^{30}$.

Wirblbahn jest jednym z niewielu prześwitów, w których zetknąć się można z doświadczeniem Zagłady. To miejsce końca poprzedniej trasy, której zaprogramowanym kresem była śmierć - i początkiem nowej, w której Siegelbaum, jak Izaak po akedzie, zostaje nieoczekiwanie uwolniony do swojego obecnego życia. Rodząc się na nowo, doświadcza faktu bycia żywym przede wszystkim jako paraliżującego bezwładu, bazowej kondycji nagiego egzystowania. Ruch, w który potem wprawione zostaje jego życie,

${ }^{29}$ Zob. Appelfeld, Droga żelazna..., s. 13-14.
${ }^{30}$ Tamże, s. 15-16. 
jest mechaniczny jak Freudowski popęd śmierci ${ }^{31}$ : przymus powtórzenia tuszuje kondycję jałowości skupionej na traumie i niezdolnej do wyjścia poza nią. Siegelbauma nawiedza wspomnienie opuszczenia wagonu:

Jakiś człowiek dotknął mojego ramienia i powiedział: „Nieźle, ale chyba za późno” - po czym natychmiast wrócił do wagonu. Pamiętam jego spojrzenie i ciche kroki. Odgłos tych kroków towarzyszy mi do dnia dzisiejszego. Ściga mnie i prześladuje, tak że niekiedy słyszę go nawet, gdy jestem w objęciach oddanej mi kobiety. Wirblbahn to rana, która się nie zagoi ${ }^{32}$.

Ów człowiek reprezentuje swoistą formę syndromu ocaleńca: jego życie zostało definitywnie przetrącone i nawet uwolnienie niczego tu nie zmienia. Jest już za późno, by można się było wywikłać z bezsensowności pustego przymusu, którego symbolem pozostaje kolej. Powrót do wagonu jest konsekwentnym przyznaniem, że nic nie może się już wydarzyć. To, że Siegelbauma prześladuje odgłos jego kroków, świadczy o tym, iż w istocie sam główny bohater znajduje się w analogicznej sytuacji, wybiera tylko dłuższą ścieżkę powrotu. W tym sensie jest jak ostatnia postać przywołana przez Freuda w tekście Poza zasada rozkoszy, patriarcha Jakub (Izrael), symbolizujący życie jako okrężną drogę, kuśtykanie, które co prawda poddaje się wyrokowi powtórzenia, ale przynajmniej na własnych warunkach, w odroczeniu nieuchronnego ${ }^{33}$.

Kolej - droga żelazna - jest więc jednocześnie obrazem-błyskiem, który łączy życie po Zagładzie z zakrytym wspomnieniem jej samej. Stanowi zarazem ucieleśnienie przymusu powtórzenia - symbol życia wywichniętego z sensownych ram i sprowadzonego do bazowej, organicznej postaci skoncentrowanej na traumie - oraz sposób odroczenia tego, co nieuchronnie powraca. Siegelbaum, wyzwolony w miejscowości Wirblbahn i nieustannie do niej powracający po to, by co roku rozpoczynać swoją wędrówkę, byłby

${ }^{31}$ W słynnym tekście Poza zasada rozkoszy Freud wiąże popęd śmierci z „demonicznym natręctwem" płynącym z podstawowej, uniwersalnej dla życia jako takiego skłonności do powrotu do tego samego: „Ale w jaki sposób to, co popędowe, związane z natręctwem powtarzania? W tym miejscu nasunąć się musi myśl, że trafiliśmy na ślad jakiejś ogólnej, dotychczas nie wyjaśnionej - czy w każdym razie nie zaakcentowanej dobitnie - cechy popędów, być może wszelkiego życia organicznego w ogóle. Popęd byłby zatem wrodzonym wszelkiemu życiu organicznemu pędem do przywracania jakiegoś wcześniejszego stanu - stanu, którego owo życie organiczne musiało się wyrzec pod wpływem siły zaburzenia zewnętrznego, czymś w rodzaju organicznej elastyczności czy też - jak kto woli - przejawem bezwładności w życiu organicznym”. Zob. Sigmund Freud, Poza zasadą rozkoszy, [w:] tenże, Psychologia nieświadomości, tłum. Robert Reszke, Warszawa 2009, s. 191.

${ }^{32}$ Zob. Appelfeld, Droga żelazna..., s. 16-17.

${ }^{33}$ Por. Freud, Poza zasada rozkoszy..., s. 213-215. 
więc alegorią przyjęcia pozagładowej kondycji, wyborem najlepszego z rodzajów życia, jakie można wieść po Szoah. Droga żelazna stanowiłaby zaś opowieść o tym, jak symbolizowaną przez żelazo konieczność uczynić można - mocą własnej decyzji - relatywną wolnością odroczenia.

\section{Stworzenie jako katastrofa}

Świat Drogi żelaznej odpowiada w swej naturze wędrówce Siegelbauma: jest rzeczywistością upadłą, pozbawioną mocy i obarczoną nieusuwalną winą; wraz z Zagładą została stworzona na nowo. Jej aktualny kształt jest zatem wynikiem katastrofy dziejowej, która położyła kres dawnemu życiu żydowskiemu. Życie bowiem ostało się tu jedynie w formie przetrwalnikowej. Opisywana przez Appelfelda kraina jest nadal zamieszkiwana przez wielu ocalałych Żydów, którzy często się ukrywają lub starają się nie rzucać w oczy swoim antysemickim sąsiadom; niektórzy, jak Siegelbaum, zdecydowali się uczynić z tułaczki sposób na życie. Zniknęła żydowska religijność w jej bezpośredniej formie - jedyne, co się ostało, to wiara w żydowski autotelicznie pojmowany rytuał i wspólnotowość, które utrzymują się w pustce powstałej przez wycofanie się Boga. Mają one podobny status jak cytowana przez Gershoma Scholema za Szmuelem Josefem Agnonem chasydzka opowieść:

Kiedy Baal-Szem miał do spełnienia coś trudnego, na przykład jakieś tajemne dzieło gwoli pożytku wszelkich stworzeń, szedł do lasu, rozpalał w pewnym miejscu ogień i pogrążony w medytacjach mistycznych zmawiał modlitwy - no i wszystko odbywato się zgodnie z jego zamierzeniami. Gdy pokolenie później podobne zadanie miał wykonać Magid z Międzyrzecza, szedł do lasu na to samo miejsce i mówił: „Ognia co prawda nie możemy już rozpalać, ale możemy zmówić modlitwę”, i wszystko było tak, jak sobie umyślił. I znów jeszcze jedno pokolenie później to samo miał wykonać rabbi Mojżesz Lejb z Sasowa. Poszedł do lasu i rzekł: „Nie możemy już rozpalać ognia, nie znamy też sposobu tajemnych medytacji ożywiających modlitwę. Znamy jednak miejsce w lesie z tym wszystkim związane - $i$ to musi wystarczyć". No i wystarczało. Kiedy w pokoleniu następnym rabbi Izrael z Rużyna stanął przed takim samym zadaniem, zasiadł w swym pałacu na złotym krześle i powiedział: „Nie możemy już rozpalać ognia, nie możemy zmawiać modlitw, nie znamy już także owego miejsca - ale możemy o tym wszystkim opowiedzieć". I to jego opowiadanie - dodaje pisarz - miało taką samą moc jak czyny spełnione przez tamtych trzech ${ }^{34}$.

${ }^{34}$ Zob. Gershom Scholem, Mistycyzm żydowski i jego główne kierunki, tłum. Ireneusz Kania, Warszawa 2007, s. 384. 
W Drodze żelaznej żywa wiara jest już trudna do wyobrażenia: pod ciężarem Zagłady załamała się sama możliwość boskiej obecności czy oddziaływania. Gdzie zniknął teistyczny judaizm, tam kiełkuje nowy, ateistyczny, skoncentrowany nie na Bogu, lecz wyłącznie na wspólnocie. Judaizm w świecie Appelfelda jest ocalaniem elementów dawnego żydowskiego świata, których język i funkcje są już dziś niezrozumiałe. Rozsiane po owej pohabsburskiej krainie ślady żydowskiego życia są ośrodkami, z których emanuje odległy, zapośredniczony odblask sensu i boskości. Nawet jedyny wzmiankowany w powieści rabin nie zajmuje się już swoją gminą - bo i tej nie posiada - ale jest kustoszem śladów:

W Sandbergu do końca dziewiętnastego wieku istniała gmina żydowska. Z biegiem lat jednak młodzi wyjechali do dużych miast, a starzy, jeden po drugim, odeszli z tego świata. Rabin Zimmel, który był wówczas młodym człowiekiem, został w Sandbergu, by otaczać opieką kilku mieszkających tam jeszcze ludzi, dbać o synagogę i jej dużą bibliotekę. W czasie wojny deportowano go razem ze starcami. Najpierw wywieziono go do Mińska, a stamtąd do obozu pracy. Potem został wysłany do obozu zagłady. Uratował się w ostatniej chwili. Ku swemu zdziwieniu, gdy po wojnie wrócił do Sandbergu, zastał synagogę zamkniętą na tę samą kłódkę, którą własnoręcznie założył. Klucz nadal leżał w schowku. Rabin Zimmel zamierzał pobyć tu tylko jeden dzień, pomodlić się na grobach przodków, a potem przyłączyć do grupy uchodźców jadących do Palestyny. Kiedy jednak przyjechał i zastał wszystko na swoim miejscu, zrobiło mu się żal synagogi, książek i postanowił, że zostanie. Opowiedziano mu, że pewna kobieta, która przed wojną całe lata pracowała w żydowskich domach, przychodziła raz w tygodniu, aby posprzątać synagoge i przyległe do niej mieszkania. Kilkakrotnie zdarzało się, że chuligani próbowali podpalić świątynię, ale kobieta groziła im karą niebios i udawało się jej przywołać ich do porządku. Zmarła kilka dni przed przyjazdem rabina ${ }^{35}$.

W ten sposób pozostałości dawnego żydowskiego świata - synagogi, meble, naczynia, książki - przybierają postać iskier ukrytych w upadłym świecie i godnych ocalenia. Ich moc nie działa bezpośrednio, lecz przez założenie - podobnie jak ochronna siła groźby wypowiadanej przez kobietę strzegącą synagogi. To, jaki zyskują status, jest bezpośrednią pochodną radykalnego załamania transcendencji, którego doświadcza rzeczywistość Drogi żelaznej. Funkcjonują one na podobieństwo zaszyfrowanych, ukrytych przejść do utraconego boskiego pierwiastka; nie ma już do nich dostępu, można jedynie rozpoznać w nich ślad dawnej praktyki wiary. Tam, gdzie nie ma już transcendencji, dawne bramy do niej zastępują jej istnienie. Radykalne zeświecczenie tej rzeczywistości oznacza również, że górę nad

${ }^{35}$ Zob. Appelfeld, Droga żelazna..., s. 133-134. 
Prawem żydowskim bierze samo istnienie Żydów i ochranianie tkanki oraz artefaktów kultury żydowskiej. U Appelfelda nie ma bezpośredniej wiary; jest tylko dzieło ocalania, przez które to, co zgubione, choć nie podlega odtworzeniu, może zostać zakonserwowane do czasu, gdy - być może - będzie mu dane odzyskać moc. W tym znaczeniu katastrofa żydowskiego życia jest wielką parabolą nowoczesności, epoki załamania transcendencji, która ani nie znika, ani nie zostaje zastąpiona przez swoją inną postać, lecz ulega zawieszeniu i petryfikacji w dawnych śladach.

Świat Drogi żelaznej jest nową, swoistą rzeczywistością, zrodzoną z totalnej zbrodni. Między nią a poprzednią epoką rozpościera się mroczny wiek, ten sam, który w kontekście swojej pamięci Appelfeld opisywał jako „tunel”. Jedynym przejściem pomiędzy tymi eonami jest ciemny punkt, podobny do Wirblbahn Siegelbauma: to ów niemożliwy locus, będąc miejscem kresu Zagłady i początkiem świata (podobny do nekudat ha-ajn w Zoharze), który się z niej wyłania, określa same ramy nowej rzeczywistości. Powtórzenie, do którego przymuszony jest bohater Drogi żelaznej, to nie tylko jego idiosynkratyczna cecha, ale rys ontologii świata po Szoah - przeciętego drogami żelaznymi rozumianymi już nie jako trasy transportów, lecz sieci przymusów, w które nieodwracalnie wplecione jest życie.

W tym rozumieniu świat drogi żelaznej powstał w wyniku specyficznego aktu stworzenia będącego zarazem katastrofą. Trudno uniknąć - wyrażanych już wcześniej - uwag o zbieżności tej wizji z kategorią cimcum w rozumieniu Izaaka Lurii ${ }^{36}$. Inaczej jednak niż chciał ją stosować do

${ }^{36}$ Przypomnijmy krótko istotę cimcum u Lurii (akronim ha-Ari). Jest to koncepcja wyjaśniająca wstępny etap kreacji, w którym pierwotna, niezróżnicowana pleroma boskiego światła (a ściślej: światła Ejn Sof) musi doznać transformacji, by uczynić miejsce stworzeniu. Zgodnie z tym, jak relacjonuje myśl Lurii Chaim Vital, przed stworzeniem nie istniało żadne puste miejsce (makom pnui), które zająć mogłyby byty. Następnie, gdy Ejn Sof podjął decyzję o stworzeniu świata, wycofał się (cimcem et acmo) w środek światła, to zaś wycofało się z centrum na obrzeża (swiwot), pozostawiając wolne miejsce (makom pnui). Zob. Chaim Vital, Sefer Ec Chaim, heichal 1, szaar 1, lit. bet, źródło: https:/www.sefaria.org/Sefer Etz_Chaim.1.2.2?lang=bi\&with=Versions\&lang2=en [dostęp: 10 maja 2019]. Zob. też Lawrence Fine, Physician of the Soul, Healer of the Cosmos: Isaac Luria and His Kabbalistic Fellowship, Stanford 2003, s. 40. Wskutek skoncentrowania Bożej obecności na obrzeżach w środku powstaje tehiru, pustka. W tym samym procesie Ejn Sof oczyścił się z elementów surowego sądu, din, które pozostały w tehiru. Stworzyły w ten sposób masę nieuformowanej materii, golem, otoczoną przez Ejn Sof. Ten wstępny etap stworzenia jest niejako przygotowaniem materiałów do właściwej kreacji. Co interesujące, metaforyka Lurii odwołuje się do instrumentarium artysty: pisarza lub rzeźbiarza. Oto bowiem po cimcum Ejn Sof wysyła promień swego światła w stronę materii golem, by ją uformować; kształtuje ją jak rzeźbę, wyłaniając z niej naczynia (kelim), które będą służyły do przyjęcia boskości. Niemniej jednak na etapie napełniania tych naczyń światłem Boga okazuje się, że nie wytrzymują one jego doskonałości. Jedynie pierwsze trzy naczynia były w stanie przyjąć wyemanowane 
pozagładowej teologii Hans Jonas, kładący nacisk na odpowiedzialność człowieka w obliczu wycofania się Boga, uwidaczniającego się z całą mocą w Szoah ${ }^{37}$, wizja Appelfelda jest bezkompromisowa i bezlitosna. Nie ma tu miejsca na moralizowanie ani miałkie usymbolicznienie Boga: Jego zniknięcie jest przede wszystkim horrendalną katastrofą natury etycznej, zanikiem ram, w których zbrodnia może być zidentyfikowana jako taka. W Drodze żelaznej żaden ze sprawców ludobójstwa nie poczuwa się do odpowiedzialności za swoje czyny. Co więcej, odczuwają dumę z własnych dokonań:

Rok temu w końcu nie wytrzymałem i podsunąłem właścicielowi hotelu karteluszek, na którym napisałem: „Gdzie pan był w czasie wojny?”

„Dotarłem aż do Stalingradu” - odpisał mi wyraźnym pismem.

„To tam pan stracił słuch?”

„Tak".

„Hitler oszukał cały świat” - napisałem.

„To nieprawda" - odpisał mi natychmiast.

„Dlaczego?” - upierałem się przy swoim.

„Hitler chciał zabić wszystkich Żydów i zrobił to” - wyjaśnił właściciel hotelu.

Gdy mu nie odpowiedziałem, dopisał dużymi literami: „To była ważna misja, która się powiodła".

„Ależ oni nadal istnieją". - Musiałem to napisać.

„To błąd” - nie zawahał się odpowiedzieć ${ }^{38}$.

Świat Drogi żelaznej jest więc nie tylko resztką po wycofanej transcendencji, ale próżnią bez Prawa, które byłoby uznawane w swojej powszechnej ważności. W tej sytuacji żydowskie życie jest świadectwem ulotnionej boskości także w tym znaczeniu, że samą swoją obecnością przywraca rzeczywistości wartość etyczną. I ten etyczny pierwiastek ma jednak

z Boga sefiry, natomiast dalsze się rozpadły. Tak powstają klipot, skorupy rozbitych naczyń, złożone zasadniczo z ciemnej materii sądu (din), które jednak więżą pojedyncze iskry światła (nicocot). Niektóre z iskier to dusze zatracone po upadku Adama. Z tej źródłowej katastrofy stworzenia wyłania się od razu potrzeba zbawienia, dokonującego się poprzez cząstkowe akty tikun, naprawy, do których powołany jest człowiek. Zob. tamże, s. 126-144; Christoph Schulte, Zimzum: Gott und Weltursprung, Berlin 2014, s. 46-48. System Lurii jest bardzo szczegółowy, a w dodatku relacje o nim, jakie dotarły do nas za sprawą uczniów Lurii, różnią się w wielu aspektach. Jednakże podstawowa struktura tej koncepcji kabalistycznej jest czytelna. Czyni ona ze stworzenia akt o podwójnym charakterze: (1) najpierw wskutek cimcum dochodzi do ograniczenia Ejn Sof i wytworzenia zarówno przestrzeni na byty, jak i materii, z której powstaną; (2) następnie zaś Ejn Sof tworzy świat; na tym etapie dochodzi jednak do katastrofy.

${ }^{37}$ Zob. Hans Jonas, Idea Boga po Auschwitz, [w:] tenże, Idea Boga po Auschwitz, tłum. Grzegorz Sowiński, Kraków 2003, s. 33-45.

${ }^{38}$ Zob. Appelfeld, Droga żelazna..., s. 18. 
paradoksalny charakter: Siegelbaum jest świadom, że właściwą karą za zbrodnię i jej otwartą afirmację powinna być śmierć, jednak nie potrafi jej wymierzyćc ${ }^{39}$. Powieść opisuje świat po czynie, gdzie nic decydującego już się nie zdarza; rzeczywistość kontynuuje swe trwanie siłą inercji wykluczającej odpowiedzialność czy karę. Zamieszkujący ów świat Żydzi są nie tylko świadkami, ale przede wszystkim jedynymi ludźmi, którzy jako kontrapunkt dla permanentnego zapomnienia i nikczemności wznoszą aktywne zachowanie życia do rangi nakazu etycznego. $Z$ tą etyką wchodzi w napięcie potrzeba pomszczenia morderców prowadząca Siegelbauma do zaplanowania zabójstwa Nachtigala. Lecz to za jego sprawą bohater osunie się na powrót w „ciemny tunel” pamięci i w żądzę zemsty oraz zniszczenia, której nie będzie się dało opanować.

\section{Tikun ha-olam po zbrodni}

Jeśli uznać Drogę żelazna za traktat filozoficzny o Zagładzie interpretowanej jako radykalne cimcum tworzące nową rzeczywistość, powinno być w niej miejsce również dla aktów naprawczych, tikunów. Tutaj Appelfeld wyraźnie gra skojarzeniami z kabałą luriańską ${ }^{40}$ : ślady żydowskiego życia w świecie po zbrodni są dla niego rozsypanymi iskrami światła, uwięzionymi w znikczemniałej pozagładowej rzeczywistości. Siegelbaum jest kupcem judaików, które to zajęcie przynosi mu co prawda dochód, ale służy przede wszystkim zgromadzeniu żydowskich artefaktów przez zaprzyjaźnionego kolekcjonera. Wspomniany wcześniej rabin Zimmel również opiekuje się zachowanym zbiorem książek i planuje napisać w sprawie kabalistycznych nabytków do Gershoma Scholema w Jerozolimie (a więc do jednego z największych fascynatów lurianizmu, zwłaszcza w jego katastroficznej wersji $)^{41}$.

Zbieranie jest więc co prawda Appelfeldowskim tikunem, jednak nie ma w swym horyzoncie zbawienia. Przyszłość w świecie Drogi żelaznej pozostaje wyznaczona jedynie rytmem powtórzeń i wpisaną weń czynnością ocalania, której wykonywanie schodzi się bez reszty z jej celem. Stworzenie świata poprzez wycofanie transcendencji i zbrodnię sprawia,

39 Tamże.

40 Zob. Miller Budick, Aharon Appelfeld's Fiction..., s. 60-77.

41 Zob. Appelfeld, Droga żelazna..., s. 90-91; Moshe Idel, Old Worlds, New Mirrors: On Jewish Mysticism and Twentieth-Century Thought, Philadelphia 2010, s. 106-150; Schulte, Zimzum..., s. 383-389. 
że nie ma on również czasowych ram: pewne jest jedynie to, że przeszłość będzie się powtarzać. W tym znaczeniu gromadzenie judaików może co najwyżej wpisać się w pracę repetycji oraz utrzymywania życia, nie będąc jednak w stanie przeciąć węzła winy i fatum.

Odpowiednikiem kolekcjonerskiej działalności żydowskich bohaterów Drogi żelaznej jest prowadzona przez nich - a przede wszystkim przez Siegelbauma - wojna z melancholią. Ta zaś jest nie idiosynkratyczną przypadłością jednostek, ale strukturalną chorobą, na którą skazane jest życie po Zagładzie ${ }^{42}$. Walka z nią nigdy nie jest wygrana, ale musi być prowadzona na podobieństwo wojny. Jako że „sprawia [ona], że życie Żyda staje się piekłem" "43, a więc w istocie zmusza życie, by po raz kolejny wróciło do rany, którą mu zadano, jest głównym przeciwnikiem ocalałego. W zmaganiach z nią Siegelbaum stosuje cały zespół strategii i technik nasuwających skojarzenia z późnymi tekstami Friedricha Nietzschego (przede wszystkim Ecce homo ${ }^{44}$ ). Melancholia jest dla niego doskonale znanym przeciwnikiem, którego należy zaskakiwać i uprzedzać - odpowiednim rytmem podróży, wizytą we właściwych miejscach, spotkaniami, kąpielami i dietą. Przegrane bitwy skutkują dla Siegelbauma koniecznością odwrotu i spędzeniem całego dnia w łóżku. Wojna z melancholią nie pozwala na choćby chwilowy odpoczynek: jest świadectwem nieustannego odporu, którego wymaga kondycja ocalonego. By móc go utrzymać, Siegelbaum potrzebuje dokonywać permanentnego rachunku sił, planować swoje kroki i być przygotowanym na nagłe ataki. Stawką tej wojny jest życie i jego przynajmniej częściowe wyswobodzenie z rytmu powtórzenia.

W Drodze żelaznej jest jeszcze jeden mesjaniczny rys. Ocaleni Żydzi są w znakomitej większości członkami podziemnej komunistycznej siatki. Organizacja jest już cieniem tego, czym była przed wojną. Co więcej, przejęła na siebie ochronę i kultywowanie żydowskiego życia do tego stopnia, że rytuały i święta ruchu robotniczego zlały się w jej praktyce w jedną całość z dawnymi pieśniami chasydzkimi. Żydowscy komuniści są u Appelfelda jak ukryci cadycy (lamedwownicy) z chasydzkich opowieści, którzy działają na rzecz ocalenia i zbawienia świata. Załamanie

${ }^{42}$ W ten sposób Droga żelazna powtarza rys dawniejszej żydowskiej historii. Przynajmniej zdaniem Scholema chasydyzm powstał jako uwewnętrznienie lurianizmu i klęski Sabbataja Cwiego właśnie w postaci melancholii. Zob. Gershom Scholem, The Messianic Idea in Judaism and Other Essays on Jewish Spirituality, New York 1995, s. 196.

${ }_{43}$ Zob. Appelfeld, Droga żelazna..., s. 193.

${ }_{44}$ Zob. Friedrich Nietzsche, Ecce homo. Jak się staje, kim się jest, tłum. Leopold Staff, Kraków 2003. 
transcendencji sprawiło, że zbawienie religijne (przez judaizm) i świeckie (przez marksizm) całkowicie się ze sobą schodzą ${ }^{45}$. Jednakże ta ukryta komunistyczna siatka nie ma żadnej realnej mocy; w najlepszym wypadku utrzymuje sama siebie. Niemniej pozostaje miejscem, w którym skrywa się - w zapośredniczonym założeniu - resztka wycofanej transcendencji, ostatnia obietnica etyki, sprawiedliwości i ocalenia.

\section{Wnioski: niejednoznaczność mesjańskiej ścieżki}

Jeśli świat Drogi żelaznej istotnie jest wariacją na temat luriańskiego cimcum, to byłaby to reinterpretacja bezlitosna, pozbawiona złudzeń, a w miejsce nadziei zbawienia oferująca co najwyżej permanentną walkę z powtórzeniem i jego trucizną, melancholią. Ocalenie polega w niej na stworzeniu nowego życia, które zostaje nieusuwalnie obciążone warunkami, w których powstało: zamknięte w rytmie powrotów i źródłowego bezsensu, pozostaje nieustannym ruchem przetrwania. Nie ma tu zasadniczo miejsca na mesjanizm bądź odkupienie. Życie nie jest wpisane w żaden historyczny horyzont, który byłby określony przez transcendencję. Gdy ta znika, pozostaje jedynie opozycja życia uwikłanego w powtórzenie i melancholię - oraz drobnych aktów samopodtrzymania i wyzwolenia.

Dialektyka tych dwóch biegunów określa rytm życia Siegelbauma, znajdując kulminację w finale dzieła. To w nim właśnie główny bohater podejmuje próbę ostatecznego - jak można mniemać - wydobycia się z powtórzenia poprzez radykalny czyn. Przez całą powieść w Siegelbaumie narasta żądza zemsty na mordercach. Najpierw pozostaje w domenie sprawiedliwości i odpowiedzialności, potem pragnienia, by wreszcie znaleźć spełnienie w działaniu. Napięcie oczekiwania na ten akt daje jednocześnie nadzieję radykalnej zmiany, rozpoczęcia procesu, który doprowadzi do metafizycznej rekonfiguracji powieściowego świata. Siegelbaum zabija Nachtigala, co jest pierwszym jego czynem niepolegającym na ocalaniu rzeczy lub zachowywaniu własnego życia. Niemniej jednak ten akt wcale nie przerywa kręgu powtórzenia i winy. Przeciwnie: wydaje się znikomy, wręcz niezauważalny wobec tak wielu morderców, którzy nie ponieśli kary. Siegelbaum wraca przerażony do Wirblbahn, uświadamiając sobie,

${ }^{45}$ Można zaryzykować myśl, że jest to następna postać opisywanego przez Emila L. Fackenheima żydowskiego paradoksu: Bóg jednego ludu jest zarazem uniwersalnym Bogiem świata. Zob. Emil L. Fackenheim, Encounters Between Judaism and Modern Philosophy: A Preface to Future Jewish Thought, New York 1980, s. 18. 
że powinien spalić to miejsce. Ten ostatni, dziwny powrót jest znakiem, że choć przymus powtórzenia wciąż działa, to jednak raz urzeczywistniona wola zemsty (czy też sprawiedliwości) radykalnie zmieni jego charakter.

Czyn Siegelbauma można traktować jako radykalny akt wymuszenia sprawiedliwości i przyspieszenia rozrachunku, którego powinien dokonać tylko mesjasz, gdyby można było weń jeszcze wierzyć. To jedyna w powieści ${ }^{46}$ szansa przełamania paradygmatu świata opartego na ocaleniu: Siegelbaum działa jak $\operatorname{din}^{47}$, kabalistyczna sefira surowego sądu, w którym wyzbyte moralnej wartości trwanie ma znów odzyskać własne znaczenie. Gdy wraca do Wirblbahn, jego życie znów się kończy. To, co czeka po drugiej stronie, nie daje się przewidzieć. Nowy świat może być zarówno kolejnym powtórzeniem, z którego nie sposób się wydostać, jak i obietnicą świeżego początku. Tonacja ostatnich zdań powieści zdaje się wskazywać na pierwszy scenariusz:

Miałem przed oczami żółte płomienie, które mieszały się z innymi, czarnymi. Było jasne, że moje życie w tym miejscu się wypaliło i skończyło. Jeśli będę miał inne życie, nie będzie ono szczęśliwe. I jak w każdym wyrazistym i długo trwającym koszmarze, widziałem morze ciemności i miałem świadomość, że w moich czynach nie było ani piękna, ani poświęcenia. Wszystko robiłem z przymusu, niezdarnie i zawsze zbyt późno ${ }^{48}$.

Przyjmijmy jednak, że ów moment nieprzewidywalności i nowego otwarcia, pomimo wszelkiego obciążenia przeszłością, spóźnienia i niezdarności, można czytać jako zbawienie, które osiąga się przez ostatni, przymusowy tikun. Jeśli tak, to nie jest on przyczynieniem się do mesjańskiego odrodzenia świata, lecz co najwyżej początkiem innego, nieszczęśliwego życia w na zawsze a-teistycznej przestrzeni.

\section{Bibliografia}

\section{1. Źródła opublikowane}

Appelfeld Aharon, Badenheim 1939, tłum. Henryk Szafir, Warszawa 2004. Appelfeld Aharon, Droga żelazna, tłum. Hanna Volovici, Warszawa 2006. Appelfeld Aharon, The Story of a Life, tłum. Aloma Halter, New York 2004.

${ }^{46}$ Jak zauważa Gila Ramras-Rauch, jest to też jedyna powieść Appelfelda o żydowskiej zemście za Szoah. Zob. Ramras-Rauch, Aharon Appelfeld..., s. 185.

${ }_{47}$ Zob. Moshe Idel, Kabała. Nowe perspektywy, tłum. Mikołaj Krawczyk, Kraków 2006, s. 203.

${ }^{48}$ Zob. Appelfeld, Droga żelazna..., s. 200. 
Benjamin Walter, Park centralny, tłum. Hubert Orłowski, [w:] tenże, Anioł historii. Eseje, szkice, fragmenty, Poznań 1996.

Celan Paul, Przemówienie z okazji przyjmowania Nagrody Literackiej Wolnego Hanzeatyckiego Miasta Bremy, tłum. Feliks Przybylak, [w:] tenże, Utwory wybrane, red. Ryszard Krynicki, Kraków 1998.

Freud Sigmund, Poza zasada rozkoszy, [w:] tenże, Psychologia nieświadomości, tłum. Robert Reszke, Warszawa 2009.

Nietzsche Friedrich, Ecce homo. Jak się staje, kim się jest, tłum. Leopold Staff, Kraków 2003.

Roth Joseph, Krypta kapucynów, tłum. Józef Wittlin, Kraków-Budapeszt 2015.

Roth Joseph, Marsz Radetzky'ego, tłum. Wanda Kragen, Kraków-Budapeszt 2015.

Schulz Bruno, Sklepy cynamonowe. Sanatorium pod Klepsydra, Kraków 1985.

Vital Chaim, Sefer Ec Chaim, heichal 1, szaar 1, lit. bet, źródło: https://www.sefaria. org/Sefer_Etz_Chaim.1.2.2?lang=bi\&with=Versions\&lang2=en [dostęp: 10 maja 2019$]$.

\section{Opracowania}

Bernstein Michael André, Foregone Conclusions: Against Apocalyptic History, Berkeley 1994.

Bielik-Robson Agata, Jewish Cryptotheologies of Late Modernity: Philosophical Marranos, London-New York 2015.

Bloom Harold, Kabbalah and Criticism, New York 1975.

Bloom Harold, Lęk przed wptywem. Teoria poezji, tłum. Agata Bielik-Robson, Marcin Szuster, Kraków 2002.

Bloom Harold, A Map of Misreading, Oxford 1975.

Coetzee John Maxwell, Whither Dost Thou Hasten?, „The New York Review of Books" (March 5, 1998).

Cohen Joseph, Voices of Israel: Essays on and Interviews with Yehuda Amichai, A. B. Yehoshua, T. Carmi, Aharon Appelfeld and Amos Oz, Albany 1990.

Fackenheim Emil L., Encounters Between Judaism and Modern Philosophy: A Preface to Future Jewish Thought, New York 1980.

Felstiner John, Paul Celan. Poeta, ocalony, Żyd, tłum. Maciej Tomal, Małgorzata Tomal, Kraków-Budapeszt 2010.

Fine Lawrence, Physician of the Soul, Healer of the Cosmos: Isaac Luria and His Kabbalistic Fellowship, Stanford 2003.

Hilberg Raul, Zagłada Żydów europejskich, tłum. Jerzy Giebułtowski, Warszawa 2014.

Idel Moshe, Absorbing Perfections: Kabbalah and Interpretation, New HavenLondon 2002.

Idel Moshe, Kabała. Nowe perspektywy, tłum. Mikołaj Krawczyk, Kraków 2006.

Idel Moshe, Old Worlds, New Mirrors: On Jewish Mysticism and Twentieth-Century Thought, Philadelphia 2010.

Jonas Hans, Idea Boga po Auschwitz, [w:] tenże, Idea Boga po Auschwitz, tłum. Grzegorz Sowiński, Kraków 2003. 
Kurz Iwona, Wagon, [w:] Ślady Holokaustu w imaginarium kultury polskiej, red. Justyna Kowalska-Leder i in., Warszawa 2017.

Laplanche Jean, Pontalis Jean-Bertrand, Vocabulaire de la psychanalyse, Paris 2007 (przekład polski: Słownik psychoanalizy, tłum. Ewa Wojciechowska, Ewa Modzelewska, Warszawa 1996).

Milchman Alan, Rosenberg Alan, Eksperymenty w myśleniu o Holocauście. Auschwitz, nowoczesność i filozofia, tłum. Leszek Krowicki, Jakub Szacki, Warszawa 2003.

Miller Budick Emily, Aharon Appelfeld's Fiction: Acknowledging the Holocaust, Bloomington-Indianapolis 2005.

Ramras-Rauch Gila, Aharon Appelfeld: The Holocaust and Beyond, BloomingtonIndianapolis 1994.

Scholem Gershom, Judaica 2, Frankfurt am Main 1970.

Scholem Gershom, The Messianic Idea in Judaism and Other Essays on Jewish Spirituality, New York 1995.

Scholem Gershom, Mistycyzm żydowski i jego główne kierunki, tłum. Ireneusz Kania, Warszawa 2007.

Scholem Gershom, Reflections on the Possibility of Jewish Mysticism in Our Time, [w:] tenże, On the Possibility of Jewish Mysticism in Our Time and Other Essays, red. Avraham Shapira, thum. Jonathan Chipman, Philadelphia-Jerusalem 1997. Schulte Christoph, Zimzum: Gott und Weltursprung, Berlin 2014.

Tomasik Wojciech, Szalony bieg. Kolej i ciemna nowoczesność, Warszawa 2015.

Przemystaw Tacik Uniwersytet Jagielloński przemyslaw.tacik@gmail.com 